\title{
Conservation Status and Habitat Preferences of Common Warthog (Phacochoerus Africanus) in Old Oyo National Park, Nigeria
}

\section{1*ADEOLA, AJ ${ }^{2}$ ADEYEMO, AI; ${ }^{2}$ EJIDIKE, BN; ${ }^{2}$ OLANIYI, OE; ${ }^{3}$ AKANDE, OA; ${ }^{1}$ AJAYI, SR; ${ }^{4}$ AZEEZ, OK}

\author{
${ }^{*}$ Federal College of Wildlife Management, Forestry Research Institute of Nigeria, P.M.B 268, New-Bussa, Nigeria. \\ ${ }^{2}$ Department of Ecotourism and Wildlife Management, Federal University of Technology, Akure, Ondo State, Ngeria \\ ${ }^{3}$ Department of Zoology, Ahmadu Bello University, Zaria Kaduna State, Nigeria \\ ${ }^{4}$ Old Oyo National Park, Nigeria \\ *Corresponding Author Email:nimibola@gmail.com; Tel: 08060763452
}

\begin{abstract}
This study assessed the conservation status and habitat preference of Common warthog in Old Oyo National Park, Nigeria using direct sighting and line transect method. The abundance estimate and encounter rate of common Warthog in the study area from 2018-2019 showed that year 2018 recorded 213 individuals at an encounter rate of $0.38 / \mathrm{km}$ while year 2019 recorded 184 individuals at an encounter rate of $0.32 / \mathrm{km}$ while the mean abundance estimate of common Warthog are $4.65 \pm 0.64$ and $1.71 \pm 0.48$ which represents 156 and 58 individuals at encounter rate of $0.55 / \mathrm{km}$ and $0.20 / \mathrm{km}$ in the wet season and dry season of year 2018 compared to year 2019 with average abundance estimate value of $4.00 \pm 0.85$ and $1.41 \pm 0.61$ which represents 135 and 48 individuals at an encounter rate of $0.47 / \mathrm{km}$ and $0.17 / \mathrm{km}$ for wet and dry season respectively. The mean age structure and sex ratio of the observed warthog population during dry and wet seasons revealed that juveniles had highest mean of age structures among the populations observed across the seasons. The habitat preference of common warthog revealed that they are mostly found in mixed woodland and open savanna with 112 observation and the lowest was recorded in the outcrop vegetation and open savanna with 21 individuals.in the wet season. During the dry season, mixed woodland/open savanna and Riparian grassland had the highest sightings of 45 and 33 individuals each. The outcrop vegetation/open savanna had the lowest observation of 1 individuals only. The study also recommends that more aspect of the ecology of the animal should be studied in details and emphasis should be placed on the habitat requirements.
\end{abstract}

DOI: https://dx.doi.org/10.4314/jasem.v25i1.12

Copyright: Copyright (C) 2021 Adeola et al. This is an open access article distributed under the Creative Commons Attribution License (CCL), which permits unrestricted use, distribution, and reproduction in any medium, provided the original work is properly cited.

Dates: Received: 02 October 2020; Revised: 26 November 2020; Accepted: 12 December 2020

Keywords: Conservation, Estimate, Status, Warthog

Conservation of wildlife is in crisis as species are declining worldwide. The major causes of declines in wildlife in developing countries are human population growth, habitat fragmentation, inadequate land use practices and management, lack of economic alternatives, social and political conflicts, and unsustainable use of resources (Myers et al. 2000; Kideghesho et al. 2007; Plumptre et al. 2008). The magnitude of these threats is greater in areas where a large proportion of human population relies directly on natural resources to sustain livelihoods (particularly protein intake) or for economic returns (e.g. trade of bushmeat, ivory or trophies) (Kideghesho et al. 2007; Plumptre et al. 2008). Genetic evidence has it that two distinct species of warthogs exist in Africa which are Phacochoerus africanus (common warthog) and the Phacochoerus aethiopicus (desert warthog) (Kleiman et al., 2004). Warthog has extends discontinuously across the sub-Saharan region of Africa. The two species of Warthog are distinguished largely through the presence and absence of functional incisors and external appearance (d'Huart and Grubb, 2005). The common warthog is distributed widely over Africa while desert warthogs occur in the sub-Saharan region of Africa and especially in south-western Ethiopia. Common warthogs (Phacochoerus africanus) are found on the savannah grasslands in almost all of Africa and sub-Saharan countries (Powell, 2003; Berger et al., 2006). Warthogs have disappeared in some areas where the human population is increasing and are therefore found in protected area in some countries. (Muwanika et al., 2006). They are diurnal animals, usually remain in a hole abandoned by other animals during the night (Treydte et al., 2006a). There is a significant sexual dimorphism; males are significantly larger than females. Warts distinguishing between sexes; males have much larger and easily seen warts with larger tusks, Juveniles are with much reduced warts and no tusks. Females live in small family groups with their offspring and the males live 
solitary or in bachelor groups (Berger et al., 2006). Warthogs are considered to be decline and face continued threats through human persecution in the form of hunting and competition for foraging habitat with domestic livestock (Muwanika et al., 2003). In areas where human persecution is intense many populations have become somewhat nocturnal, a change from their normal diurnal lifestyle (Kingdon, 1979).Warthogs are limited in numbers and possibly possess discontinuous distribution, contracting range, and potential levels of exploitation qualify this species for the 'Vulnerable' category (International Union for Conservation of Nature, 1996). Little is known about the size of wildlife population in West Africa National Parks and other areas where wildlife management is practiced (Aneni and Osaguona, 2005). Existing figures are mere guesses with no indication on the degree of accuracy. Continuous monitoring of size of wildlife population is basic requirement for proper wildlife management; hence population counts should be made at least once a year. Effective management of wildlife resources depend basically on the knowledge of some ecological factors, their population, distribution, migratory patterns and their ecological niches and other components (Ayeni 2007). Habitat influences the presence, abundance, distribution, movement and behavior of game animals (Musila et al., 2001). A major problem facing wildlife conservation is increasing rate of habitat loss due to human activities through the destruction of their natural habitats leading to the reduction in wildlife population (John and Skorupa, 2007). Habitat quality and quantity have been identified as the primary limiting factors that influence animal population dynamics (Jansen et al., 2001). Current and adequate information on Common warthogs richness of Old Oyo National Park is Limited. Also there is relatively little information on the population distribution, abundance and habitat preference of this animal in Old Oyo National Park. Finding from this study will enhance effective conservation and management of Common warthog. Data collected on this species of Warthog will likely be beneficial to the management of Old Oyo National Park. Hence this study assess the conservation status and habitat preference of Common warthogs (Phacochoerus africanus) in Old National Park, Nigeria.

\section{MATERIALS AND METHODS}

Study Area: Old Oyo National Park is in the ecotone of derived savanna and Southern guinea savanna of the South-Western part of the country. It lies between longitude $8^{\circ} 15^{\prime} \mathrm{E}$ and $9^{\circ} \mathrm{E}$ and latitude $3^{\circ} 45^{\prime}$ and $4^{\circ} 20^{\prime} \mathrm{N}$ covering a total area of approximately 2,450 $\mathrm{km}^{-2}$ (Jaiyeola et al., 2012). The vast guinea savannah ecotype with luxuriant grass, browse plants species and water supports grazing of ungulates. Unfortunately, this very attributes in vegetation also attracts herdsmen who encroaches on the park annually; illegal grazing of livestock has therefore become the greatest problem confronting the management of Old Oyo National Park, an act that was prohibited by section 30 of Decree 36 of 1991.

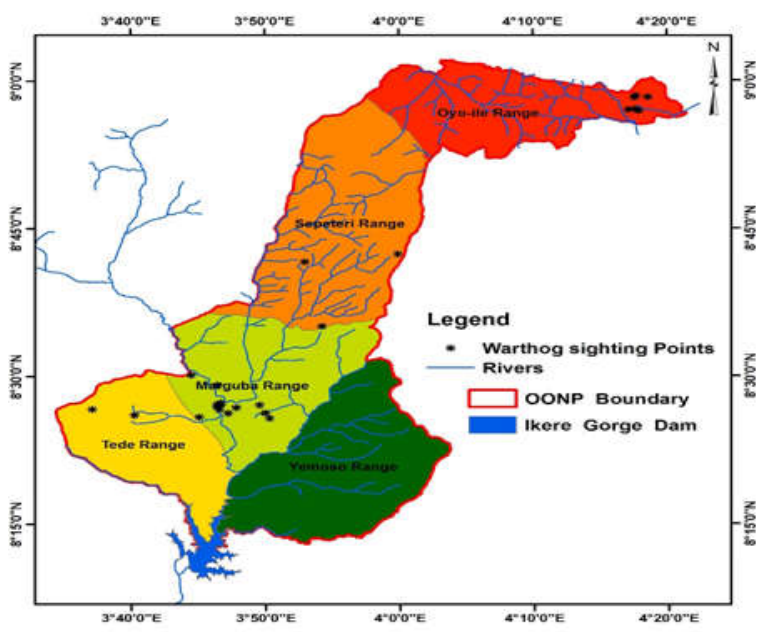

Fig 1: Map of Old Oyo National Park Showing Sampling Point

Data Collection: A Reconnaissance survey was carried out in the study area prior to the detailed study to identify areas of concentration of Warthogs in the Park. Data were collected for both wet and dry season using direct sighting, using population studies method described by Buckland et al., (2001) and line transect method using the existing jeep tracks as described by Suthelad (1997) were used. The locations were transverse in the morning between (07:00 and 11:00 a.m) and in the evening (16:00 to 18:00 hours), binocular was used for viewing of animals of long distances. The age and sex of individual were determine using the method described by Cummings (1970). Data were analysed using the Paleontological Statistics Software (PAST) for scientific data analysis.

\section{RESULTS AND DISCUSSION}

Table 1 revealed the abundance estimate and encounter rate of common Warthog (Phacochoerus africanus) in Old Oyo National Park, Nigeria from 2018-2019. In which year 2018 recorded 213 individuals at an encounter rate of $0.38 / \mathrm{km}$ while year 2019 recorded 184 individuals at an encounter rate of $0.32 / \mathrm{km}$. The table further revealed the mean abundance estimate of common Warthog ( $P$. africanus) with abundance value of $4.65 \pm 0.64$ and $1.71 \pm 0.48$ which represents 156 and 58 individuals at encounter rate of $0.55 / \mathrm{km}$ and $0.20 / \mathrm{km}$ in the wet season and dry season of year 2018 compared to year 2019 with average abundance estimate value of 
$4.00 \pm 0.85$ and $1.41 \pm 0.61$ which represents 135 and 48 individuals at an encounter rate of $0.47 / \mathrm{km}$ and $0.17 / \mathrm{km}$ for wet and dry season respectively. Table 2 showed the population distribution of Common warthog in Old Oyo National Park across the two seasons in different ranges. A total number of 397 individuals were recorded in both seasons in the study area. Wet season recorded 291 individuals while dry season recorded 106 individuals. The table further showed that Tede range had the highest occurrence of Common Warthogs with 103 individuals, followed by Sepeteri range with 88 individuals while the least was recorded in Oyo-Ile range with 21 individuals. The population density estimate of Common Warthog were presented in Table 3, in which a total 397 individuals were observed for both year 2018 and 2019 respectively. The table further reveal the overall encounter rate (per $\mathrm{km}$ ) of $2.00 \pm 1.42$ with overall effective strip width $(\mathrm{m})$ of $100.30 \pm 12.65$. The mean age structure and sex ratio of the observed warthog population during dry and wet seasons in OONP are revealed in table4, in which the juveniles had highest mean of age structures among the populations observed during the wet season with $10.75 \pm 1.92$ and this is closely followed by adult female with $10.38 \pm$ 2.11 while the least was recorded for sub adult male with $3.00 \pm 0.93$. The adult males had $5.50 \pm 0.96$, while the least was recorded for sub adult with 4.50 \pm 0.87 . In the dry season, the highest mean was estimated also for the juveniles with $5.75 \pm 1.67$ and adult males with $2.38 \pm 0.80$ and this is followed by sub - adult males $1.88 \pm 0.44$. The least was estimated for sub adult male with $0.80 \pm 0.30$.

Table 1: Population Status of Warthogs in Old Oyo National Park from 2018-2019

\begin{tabular}{|c|c|c|c|c|c|}
\hline Year & Season & $\begin{array}{l}\text { Individual } \\
\text { Observed }\end{array}$ & $\begin{array}{l}\text { Abundance Estimates } \\
(\text { Mean } \pm \text { SE) }\end{array}$ & $\begin{array}{l}\text { Encounter } \\
\text { rate/km }\end{array}$ & $\begin{array}{l}\text { Overall Encounter } \\
\text { rate/km }\end{array}$ \\
\hline \multirow[t]{2}{*}{2018} & Wet & 156 & $4.65 \pm 0.64$ & 0.55 & 0.38 \\
\hline & Dry & 58 & $1.71 \pm 0.48$ & 0.20 & \\
\hline \multirow[t]{2}{*}{2019} & Wet & 135 & $4.00 \pm 0.85$ & 0.47 & 0.32 \\
\hline & Dry & 48 & $1.41 \pm 0.61$ & 0.17 & \\
\hline \multicolumn{2}{|l|}{ Total } & 397 & & & \\
\hline \multicolumn{2}{|c|}{$\begin{array}{l}\text { Overall mean } \\
(\text { mean } \pm \mathrm{SE})\end{array}$} & $\begin{array}{l}100.00 \pm \\
27.58\end{array}$ & $3.78 \pm 0.41$ & $\begin{array}{l}0.17 \pm \\
0.05\end{array}$ & $0.35 \pm 0.03$ \\
\hline
\end{tabular}

Table 2: Distribution of Common Warthogs in Old Oyo National Park

\begin{tabular}{lllll}
\hline Seasons & Sepeteri & Marguba & Tede & Oyo - Ile \\
\hline Wet & 88 & 79 & 103 & 21 \\
Dry & 33 & 23 & 49 & 1 \\
Total & 121 & 102 & 152 & 22 \\
Mean \pm SE & $60.5 \pm 27.5$ & $51.0 \pm 28.0$ & $77.5 \pm 28.5$ & $11.0 \pm 10.0$ \\
\hline
\end{tabular}

Table 3: Population Density Estimate of Common Warthog Observed in Old Oyo National Park from 2018-2019

\begin{tabular}{llll}
\hline Estimate & Dry season & Wet season & Overall \\
\hline Observed individual & 106 & 291 & 397 \\
Encounter rate (per km) & $0.81 \pm 0.52$ & $1.39 \pm 0.99$ & $2.00 \pm 1.42$ \\
Effective strip width $(\mathrm{m})$ & $100.30 \pm 22.30$ & $97.70 \pm 14.99$ & $100.30 \pm 12.65$ \\
Density (Warthog's km ${ }^{-1}$ ) & $4 . .06 \pm 2.24$ & $7.11 \pm 4 . .62$ & $9.97 \pm 6.63$ \\
\hline
\end{tabular}

Table 4: Age structure and sex ratio of the observed Warthog (Phacochoerus africanus) population during dry and wet seasons in OONP

\begin{tabular}{llllll}
\hline Wet & \multicolumn{4}{c}{ Mean of Individual Seasons } \\
$\begin{array}{llll}\text { Age Structure } \\
\text { Am }\end{array}$ & $\begin{array}{l}\text { Individual } \\
\text { Observation }\end{array}$ & Mean \pm SE & $\begin{array}{l}\text { Dry } \\
\text { Individual } \\
\text { observation }\end{array}$ & Mean \pm SD & Mean diff. \\
Af & 59 & $7.28 \pm 1.16$ & 19 & $2.38 \pm 0.80$ & $4.90 \pm 0.36$ \\
Sam & 81 & $10.38 \pm 2.11$ & 19 & $2.38 \pm 0.73$ & $8.00 \pm 1.38$ \\
Saf & 24 & $3.00 \pm 0.93$ & 7 & $0.80 \pm 0.30$ & $2.20 \pm 0.63$ \\
$\mathbf{J}$ & 42 & $5.25 \pm 1.03$ & 15 & $1.88 \pm 0.44$ & $3.37 \pm 0.59$ \\
\hline \multicolumn{4}{c}{ Am = Adult male, Af= Adult female, Sam $=$ Sub-adult male, Saf= sub-adult female, J=juvenile }
\end{tabular}

Fig 2 revealed the habitat preference of Common warthogs in the study area, in which mixed woodland and open savanna had the highest observation of 112 individuals sighted and this is followed by dense woodland and forest outlier habitat with 81 individuals in the wet season. The lowest was recorded in the outcrop vegetation and open savanna with 21 individuals. During the dry season, mixed woodland/open savanna and Riparian grassland had the highest sightings of 45 and 33 individuals respectively. The outcrop vegetation/open savanna had the lowest observation of 1 individuals only. In 
order to manage the population of Common warthogs properly and to take conservation measures accordingly, estimating their population in the study area is important. The study was carried out in two season's i.e dry and wet seasons of year 2018-2019. This was important in order to observe the influence of the different seasons on the vegetation cover and hence, the distribution of animals. On the average individuals were counted in the whole study area. More warthogs were counted during the wet than the dry seasons. This can be attributed to the fact that it is during the wet season that furrowing takes place in most warthogs.

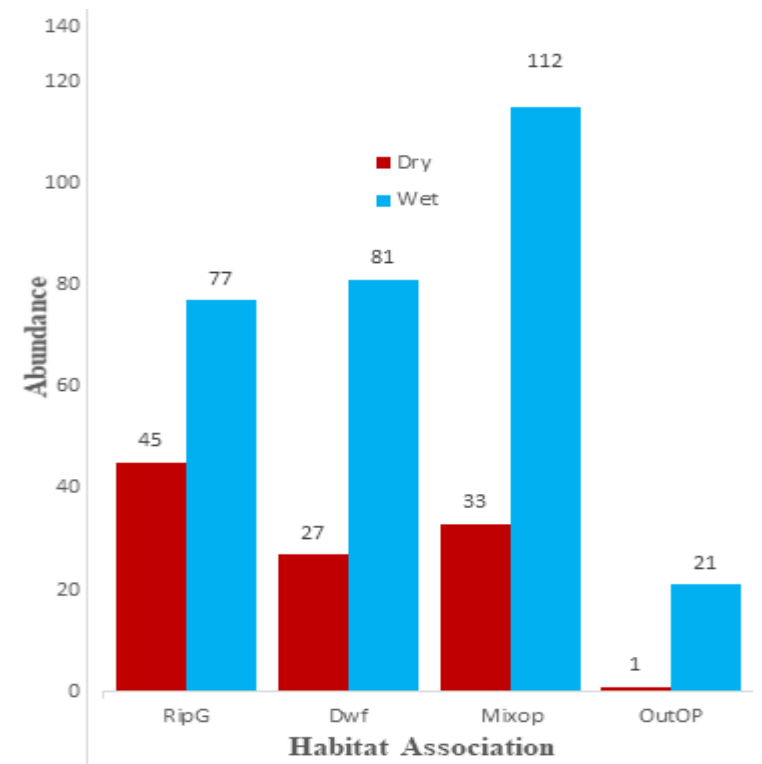

Fig 2: Habitat Preferences of Common Warthog in OONP Rip $G=$ Riparian grassland, $D w f=$ Dense woodland and forest outlier, Mixop $=$ Mixed and open woodland, Outop $=$ outcrop and open savanna

This was in line with the study of Deribe et al. (2008) that study population status and diurnal activity patterns of the common warthog (Phacochoerus africanus) in the bale mountains national park in Ethiopia. Also Boshe, (1984) reported that young Warthogs are born at the end of the dry season and beginning of the wet season which resulted into a population build up in the wet season. Furthermore, there could probably be high rate of mortality in the dry season due to physiological stress as a result of shortage of food and water. Kumsa and Bekele, (2013) also reported that high number of Warthog observed during the wet season may be due to the availability of food items and cover. During the dry season, when availability of food item declines, Warthogs may migrate to other localities in search of food and cover. This is well confirmed by the results of the present study. Furthermore, there could probably be high rate of mortality in the dry season due to physiological stress as a result of shortage of food and water (Daribe et al., 2008). The findings of this study was not in accordance with the study of Abdulfatah and Demeke, (2017) which reported in their work that Warthog are widely distributed across the two seasons and habitat. The wide distribution of Warthog in most season and habitat types might be due to their behaviour and access to resources. Overall density estimates (Warthog's km-1) of $9.97 \pm 6.63$ obtained in this study was very high compared $4.0 / \mathrm{km}^{2}$ obtained by Deribe et al. (2008). The population density of common Warthog had been established to differ from one region to another as a result of variation in environmental factors such as cover, food, water which all depends on rainfall and length of the growing season as well as suitability of their habitat (Gutema, 2015). The knowledge of sex and age distribution of individual mammals is vital for evaluating the viability of a species. Sex and age structure of a population at any given point of time is also an indication of the viability of the population (Deribe et al., 2008) in addition to the structure and dynamics of the population (Wilson et al. 1996). Sex and age structure of a population at any given point in time is also an indicative of the status of the population (Woolf and Harder, 2009). It was difficult to categorize the young into male and female in the field as their primary sexual characteristics were not easily visible. Therefore, only the sex of sub-adult and adult individual was determined. The result of the present study revealed that juvenile recorded highest numbers of individuals in all the ranges. This shows a healthy, increasing trend of warthog population in the study area, this was in agreement with findings of Boshe (1981) in the Eastern Salous Game Reserve, Tanzania and Deribe et al. (2008) in Ethiopia. The finding also showed that there are more females than males. This is in line with (Deribe et al., 2008; Adeola et al., 2020), they reported that female biased sex ratio among adults in many adults ungulate population exist. The existence of more females and juvenile are expected to increase the population in the area. A comparatively high ratio of females in the population indicated that the common Warthog have a potential to replace it and can tolerate the human disturbance. This shows healthy, increasing trend of Warthog population in the study area. The presence of more females in the population was also expected (Cumming 1975). Low number of male Warthog recorded in this study may be due to the reason that the males are subjected to high levels of mortality probably due to their wandering habits and getting exposed to predators as they move away from the hide outs, in addition to isolation from the group by the time they mature. Hunting also affects adult males more than females since they are chosen for their large size as observed 
in different animals (Deribe et al., 2008). Cumming (1975) explains that sex ratio of adults was significantly associated with the specific month and this was largely due to a marked drop in the proportion of adult males after the rut in each year. The reasons for this post furrow decline in the proportion of males are not known but there is circumstantial evidence to suggest that it may be a combination of changes in the behavior of adult males and increased mortality following the furrow. These factors may have contributed to the small proportion of adult male in the study area. An increase of the young numbers recorded during the wet season observations suggested that furrowing took place at the beginning of the wet season. Piglets were usually hidden among the dense tall grasses under the bushes until they can fully follow the parent herd. In addition, they do not appear in the vicinity of their burrows before a week after parturition (Child et al., 1968). As a result, the numbers of piglets could be underestimated although they are quite vulnerable to predation at this stage. During the census, piglets started accompanying their mothers in the vicinity of the burrows and stayed with their mother all day long after the first week. The distribution of warthogs in different habitat types varied depending on the season. Wildlife herbivores are reported to have preferred habitat types and dependence of species habitat relationship on factors ranging from where nutrients and water in-take could be maximised together with other several process that operate simultaneously at different scale of influence (Kummsa and Bekele, 2013). The finding of the present study revealed that presence Common warthog in all the four sub-vegetation types in OONP showed a wider distribution and utilization of the habitat which indicates there is a very a very strong relations between the habitat and common warthogs in the two Parks. This may not be unconnected with the accessibility of nutritional requirements, water and vegetation cover in those areas. The finding is in agreement with the statement by Girma et al., (2012) who reported that the distribution and habitat association of mammals are often correlated mainly with the availability of water, food and cover.

Conclusion: It can be concludes from the studies that the Common warthogs still exist in abundance density in the study area with overall abundance of 397 . Wet season recorded the highest number of observation with Tede and Sepeteri range recording the highest number of observation. In respect to population structure, Juvenile and Adult female scores the highest observation. The study recommends that more aspect of the ecology of the animal should be studied in details and emphasis should be placed on the habitat requirements.

\section{REFERENCES}

Abdulfatah, A. and Demeke, D. (2017). Population Size, habitat association of Common Warthog (Phacochoerus africanus) and their impact on agricultural crops around Diregudo forest in Gololcha woreda, South East, Ethiopia. Inter. J. Sci. Res. Pub. 7 (7), 192-218.

Adeola, A.J., Adeyemo, A.I. and Ejidike, B.N. (2020). Population Status and Habitat Preferences of Common Warthog (Phacochoerus Africanus) in Kainji Lake National Park. J. Res. Forestry. Wildlife Environ. 11(4), 64-69.

Aneni, T.I. and Osaguona, P.O. (2005). Wildlife Studies along Oliriver in the Kainji Lake National Park. Nig. J. Appl. Sci. 23. 144-148.

Ayeni, J.S.O. (2007).Clinical Methods for the assessment of the effect of environmental stress on fish health United States Fish and Wildlife Service, Federal Government Series Technical Papers pp: 89.

Berger, E.M., Leus, K., Vercammen, P. and Schwarzenberger, F. (2006). Faecal steroid metabolites for non-invasive assessment of reproduction in common warthogs (Phacochoerus africanus), red river hogs (Potamochoerus porcus) and babirusa (Babyrousa babyrussa). Anim. Reprod. Sci. 91, 155-171.

Boshe, J. (1984). Demographic characteristics of the warthog population of the eastern Selous Game Reserve, Tanzania. Afr. J. Ecol. 22: 43- 47.

Cumming DHM (1975). A field study of the ecology and behavior of warthog. Natl. Mus. Monum. Rhod. 7:1-7.

Deribe, E., Bekele, A. and Balakrishnan, M. (2008). Population Status and Diurnal Activity Patterns of the Common Warthog (Phacochoerus africanus) in the Bale Mountains National Park, Ethiopia, Inter. J. Ecol. Environ. Sci. 34 (2): 91-97.

d'Huart, J.P. and Grubb, P. (2005). A photographic guide to the differences between the Common Warthog. In: Suiform Soundings, IUCN/SSC Pigs, Peccaries Hippos Spec, Newslett. 5:4-8.

IUCN (1996). International Union for Conservation of Nature (IUCN). Red list of Threatened Animals. Gland Cambridge, p. 191. 
Jansen R.R., Little, E.R. and Crowe T.M (2001). Habitat Constraints Limits the distribution and population density of redwing francolin, Francolinu levaillantiiin the highland grasslands of Mpumalanga province, South Africa, Eth. J. of Bio. 4:146-155.

Jayeola O. A., Onadeko S. A., Mafiana C. F., Inah E. I. and Okeyoyin O. A. (2012). Past and present status of kob (Kobus (Adenota) kob (Erxleben) in Nigeria, Inter. J. Biodiv. Conserve. 4(5). 197-205

John A.D and Skorupa, J.P (2007) Responses of Reforest Primates to habitat disturbance: A review. Inter. J. Primatol 8:157-191.

Kingdon, J. (1979). East African Mammals, Vol. IIIB, Large Mammals: An Atlas of Evolution in Africa. Academic Press, London pp. 471-474.

Kideghesho, J.R., Røskaft, E. and Kaltenborn, B.P. (2007). Factors influencing conservation attitudes of local people in western Serengeti, Tanzania. Biodiv. Conserve. 16: 2213-2230.

Kleiman, D.G., Geist, V. and McDade, M.C. (2004). Grzimek's Animal Life Encyclopedia. The Gale Group Inc. pp. 24-36.

Kumssa, T and Bekele, A. (2013). Population status and activity pattern of desert warthog (Phacochoerus aethiopicus) in Abijata-Shalla Lakes National Park, Ethiopia. Acad. J. Environ. Sci. 1(1): 009-017.

Myers, N., Mittermeier, R. A., da Fonseca, G. A. B. and Kent, J. (2000). Biodiversity hotspots for conservation priorities. Nature 403: 853-858.
Musila M. W., Kinyamario I.J and Jungrius, K. (2001). Vegetation Dynamics of Coaster Sand Dunes near Malindi, Kenya, Afr. J of Ecol. 39:170-177.

Muwanika VB, Nyakaana S, Siegismund HR. and Arctander P (2003). Phylogeography and population structure of the common warthog (Phacochoerus africanus) inferred from variation in mitochondrial DNA sequences and microsatellite loci. Heredity 91:361-372.

Plumptre, A.J., Kujirakwinja, D. and Nampindo, S. (2008). Conservation of landscapes in the Albertine Rift. Pages27-34 in Redford, K.H. and C. Grippo. eds. Protected areas, governance and scale. Working Paper N-36, Wildlife Conservation Society, Bronx, New York.

Sutherland, W.J (1997). Ecological census Technique. Cambridge University Press. Cambridge Great Britain Pp. 336.

Treydte, A.C., Bernasconi, S.M., Kreuzer, M. and Edwards, P.J. (2006a). Diet of the Common Warthog (Phacochoerus africanus) on former cattle grounds in a Tanzanian savanna. $J$. Mammalogy. 87, 889-898.

Wilson, D. E., Cole, F. R., Nichols, J. D., Rudran, R. and Foster, M. S. (1996). Measuring and Monitoring Biological Diversity. Standard Methods for Mammals. Smithsonian Institution Press, Washington, DC. 364 pages. 